Meta

Journal des traducteurs

Translators' Journal

\title{
Television as a Source of Information for the Deaf and Hearing Impaired. Captions and Sign Language on Austrian TV
}

\section{Ingrid Kurz et Brigitta Mikulasek}

Volume 49, numéro 1, avril 2004

Traduction audiovisuelle

Audiovisual Translation

URI : https://id.erudit.org/iderudit/009023ar

DOI : https://doi.org/10.7202/009023ar

Aller au sommaire du numéro

Éditeur(s)

Les Presses de l'Université de Montréal

ISSN

0026-0452 (imprimé)

1492-1421 (numérique)

Découvrir la revue

Citer cet article

Kurz, I. \& Mikulasek, B. (2004). Television as a Source of Information for the Deaf and Hearing Impaired. Captions and Sign Language on Austrian TV. Meta, 49(1), 81-88. https://doi.org/10.7202/009023ar
Résumé de l'article

Les auteurs présentent le développement des services offerts aux sourds et aux malentendants par l'organisme autrichien de radiodiffusion ORF. En 1985, l'ORF a introduit le sous-titrage du journal télévisé du soir, à l'heure de grande écoute, et des magazines d'actualité les plus importants. Actuellement, il diffuse quelque 2160 heures annuelles de programmes sous-titrés. En rendant ainsi $12,5 \%$ des émissions télévisées accessibles aux téléspectateurs sourds et malentendants, l'ORF se place en tête des chaînes de langue allemande. L'usage de la langue des signes est par contre encore relativement limité à la télévision autrichienne. 


\title{
Television as a Source of Information for the Deaf and Hearing Impaired. Captions and Sign Language on Austrian TV
}

\author{
INGRID KURZ \\ University of Vienna, Vienna, Austria \\ ingrid.kurz@univie.ac.at
}

BRIGITTA MIKULASEK

Sign language interpreter, Austria

\section{RÉSUMÉ}

Les auteurs présentent le développement des services offerts aux sourds et aux malentendants par l'organisme autrichien de radiodiffusion ORF. En 1985, l'ORF a introduit le sous-titrage du journal télévisé du soir, à l'heure de grande écoute, et des magazines d'actualité les plus importants. Actuellement, il diffuse quelque 2160 heures annuelles de programmes sous-titrés. En rendant ainsi 12,5\% des émissions télévisées accessibles aux téléspectateurs sourds et malentendants, l'ORF se place en tête des chaînes de langue allemande. L'usage de la langue des signes est par contre encore relativement limité à la télévision autrichienne.

\section{ABSTRACT}

The paper sets out to describe the development of services for the deaf and hearing impaired provided by the Austrian Broadcasting Organization (ORF). In 1985, captions were introduced for the prime-time evening news bulletin and for the major news magazines. At present, ORF provides captions for approximately 2,160 program hours annually, giving it a leading position among German-language broadcasting organizations and making $12.5 \%$ of the total ORF television output accessible to deaf and hearingimpaired persons. The use of sign language on Austrian television, however, is still fairly limited.

\section{MOTS-CLÉS/KEYWORDS}

deaf and hearing-impaired TV audience, TV captions, TV sign language interpreting, TV services for the deaf and hearing impaired, media interpreting

\section{Introduction}

In his message to the xirth World Congress of the Federation of the Deaf, which was held in Vienna in 1995, the Austrian President wrote:

[...] deafness is one of those handicaps the worst effect of which is not physical pain but a dangerous isolation of the person afflicted. But this danger is not a fate that cannot be averted. It is very much up to the community whether or not deaf people will be left to cope with their problems by themselves. (Klestil 1995:1)

One way of helping the deaf and hearing impaired to get out of their isolation is to give them access to the visual mass media, which are of paramount importance when information of general interest is disseminated. This is why the World Federation of 
the Deaf and its member organizations are making efforts to persuade the national broadcasting organizations to meet the needs of deaf persons by increasing the number of signed programs and providing more programs with sign language interpretation and subtitles (Mäkipää \& Hämesalo 1993).

Like their hearing counterparts, deaf and hearing-impaired persons like to watch television. How widespread are captions or sign language for these audiences? To what extent are broadcasters catering to the deaf and hearing impaired? What are the special language needs of these groups and how well are these needs being met?

This article will look at access to the media for deaf and hearing-impaired persons in Austria. It will describe the development of services for this target group provided by the Austrian Broadcasting Organization (ORF) and the shifts of perception in this area.

\section{Captions and sign language on the TV screen}

\subsection{The target group}

There are more than 500,000 hearing-impaired persons in Austria. Of these, approximately 8,000 are completely deaf. This group comprises two subgroups with different preferences: persons who were born deaf and persons with acquired hearing loss. Persons who were born deaf (the Deaf community) regard sign language as their mother tongue and would like to see it used on TV. Persons with acquired loss of hearing and severely hearing-impaired persons, who represent the majority of the target group, are usually not familiar with sign language and, therefore, prefer captions:

On peut distinguer deux groupes distincts dans la communauté des sourds: ceux qui sont nés sourds et ceux qui ont connu plus tard des troubles d'audition. Leurs besoins et leurs perspectives sont différents. Les premiers ont pour moyen principal de communication la langue des signes: leur aptitude à recourir aux sous-titres peut être gênée par leur faible capacité de lecture. Les seconds ont pour la plupart reçu une éducation avec les bien entendants: leur vitesse de lecture peut être par conséquent assez élevée. (De Linde 1996: 181)

In statistical terms, the hearing impaired in Austria account for about 16\% of the total population, which makes them the largest group of persons with a handicap. In the age group over 60 , they represent as high as $30 \%$.

\subsection{Socio-political background}

Why would people who can't hear need television? Fortunately, this question, which was still being asked in the early 1980's, is a matter of the past. There have been major shifts of perception in this area, coupled with an improved recognition of the particular communication needs of deaf and hearing-impaired persons. We now have a better understanding of the linguistic, educational, political, social and psychological aspects of access to the media and there is general agreement that insofar as it is technologically feasible, all people have the right to access to information and entertainment: "Il faut que les sourds aient accès à la culture, à la formation, à l'information, qu'ils puissent exercer pleinement leur citoyenneté [...]" (Seleskovitch 1997: 562) 
For a long time the deaf received financial support from the welfare offices for the purchase of text telephones but not for television sets with a Teletext decoder because television was simply considered a luxury. In the meantime, Teletext decoders have become recognized 'auxiliary appliances' for deaf persons, as there is awareness that there can be no integration without access to comprehensive information.

In 1997 an anti-discrimination provision was included in the Austrian Constitution, providing a new legal basis for handicapped persons in Austria.

\subsection{Captions or sign language?}

There are two alternative ways of giving the deaf and hearing impaired access to television: a. captions or b. the use of sign language in different forms, ranging from an insert showing a sign language interpreter to sign language moderators. As a rule, broadcasters prefer subtitling, arguing that this is more cost effective and allows them to reach the entire target group of deaf and hearing-impaired persons, whereas sign language would be addressed to a small group only (an estimated 30,000 persons in Austria) (Grbić 2002:186). This view is not shared by the deaf community, which calls for the 'recognition of sign language' (Kellett Bidoli 2001) and its use in current affairs programs.

\section{ORF and its services for the deaf and hearing impaired}

Before 1980, watching television was 'pictures only', i.e. largely incomprehensible, for the deaf and hearing impaired in Austria. With the advent of 'Teletext' in January 1980 , providing the audience with 24-hour news and service information, television became a source of information for the deaf and hearing impaired. They now had access to continually updated written information in the areas of politics, economy, sports, arts and education, etc.

\subsection{The early days of subtitling}

The next step was the introduction of subtitling in December 1980. Since then, broadcasts where captions are screened via the teletext system have been available for the benefit of persons with a hearing handicap.

[...] la télévision [...] est diffusée vers un large public mêlant sourds et non-sourds. Des recherches $[\ldots]$ montrent très tôt qu'en dépit du grand nombre de téléspectateurs favorable aux sous-titres, les producteurs hésitent à risquer la moindre perte de revenus publicitaires qui résulterait d'une baisse de l'indice d'écoute. [...] La solution vint avec l'invention des sous-titres intégrés aux signaux de diffusion et visibles seulement pour ceux qui avaient un décodeur approprié. (De Linde 1996:173ff.)

Initially, captions were used for a daily counselling and self-help TV program (Wir). Subsequently, the use of captions was continuously expanded. In an effort to cater to the needs and wishes of the target group as much as possible, ORF program makers conducted repeated surveys.

In the early stages the use of captions was largely confined to entertainment programs and popular TV series (Tatort, Kottan, etc.). Very soon, however, the need for the deaf and hearing impaired to have access to information formats became 
apparent, and captions were gradually extended to other programs including news and current affairs. In 1985, it was decided to introduce captions for the prime-time evening news bulletin (ZIB, at 7:30 p.m.) and for the major news magazines.

Figure 1 shows the continuous expansion of captioned programs on Austrian TV since 1991.

FIG. 1

Development of subtitling for the deaf and hearing impaired on Austrian TV since 1991 (hours/year)

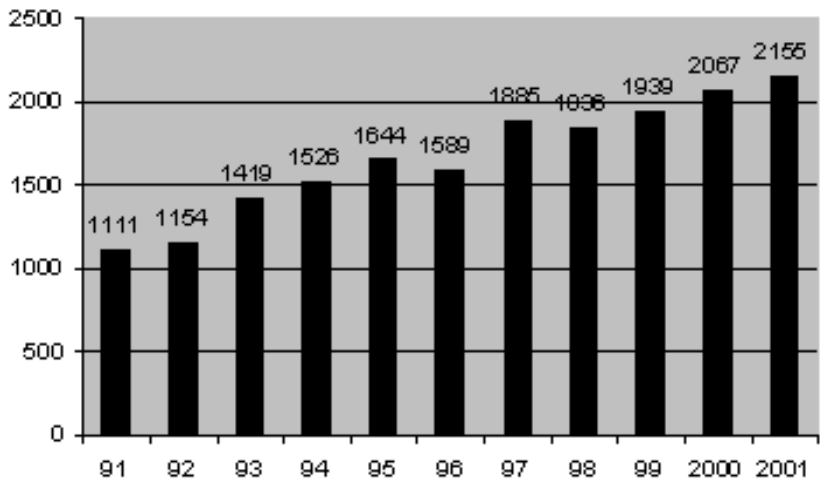

\subsection{Current situation}

At present, ORF airs about 2,160 program hours of captioned TV programs annually, covering all major types of programs, with special emphasis on ORF highlights. Since November 2001, captions have also been used for the early evening news (ZIB at 5:00 p.m.).

A breakdown over the various types of captioned program shows the wide range of coverage accessible to the deaf and hearing impaired (in approximate hours per year):

- 680 hours information, science, news \& current affairs (including news bulletins at 5:00 and 7:00 p.m., news magazines and political documentaries)

- 150 hours sports (including a weekly sports magazine, soccer, skiing, Formula 1 car races, etc.)

- 168 hours cultural programs

- 66 hours religion (including a Sunday magazine)

- 280 hours children's programs, young people and family broadcasts

- $\quad 645$ hours feature films (25-30 films per month as well as 4-5 new productions /month)

- 170 hours entertainment/TV series (ORF productions or co-productions, e.g. Kommissar Rex, MA 2412, Schlosshotel Orth, Julia, Kaisermuehlen Blues, Medicopter)

Altogether, about $12.5 \%$ of ORF's total television output are accessible to the deaf and hearing impaired.

\subsection{Sign language interpreting}

Starting in the mid-1980's, sign language interpretation was used for Mini-ZIB, a short news bulletin for children (every first Sunday of the month). In the mid-1990's this 
program was dropped. Since then, sign language interpretation (in combination with captions) has been used for Wochenschau, a 25-minute weekly magazine that is aired on Sundays at 1:05 p.m. on ORF2 as well as on 3sat (an international German-language TV program aired by ORF, Germany's ZDF and ARD and Swiss SRG).

Prior to the introduction of this service ORF produced a sample tape showing three alternatives (sign language interpreting only, captions only, a combination of sign language interpreting and captions) in order to elicit the preferences of the deaf community. The majority of votes was in favor of a combination of sign language for the moderation (text read by the news presenter) and captions for the VT recordings.

While in many ways similar to the practice of simultaneous interpreting in other settings, simultaneous interpreting for television broadcasts is fraught with additional difficulties and poses special challenges for the interpreter.

Empirical evidence has shown that expectations regarding the quality of media interpreting are particularly high: "L'interprétation à la télévision, ça ne pardonne pas." (Moreau 1998: 227)

Interpreters working for the media should be aware that speed is of the essence. They must endeavor to be very quick without 'hanging over' excessively after the speaker has finished (Kurz 1990, 1997): “[...] l'interprète pour les médias doit s'efforcer [...] d'être très rapide, sans décalage excessif par rapport à l'orateur, surtout à la fin du discours." (Kurz \& Bros-Brann 1996: 212) The same holds true, of course, for sign language interpreting on television:

The programme maker is most concerned with timing. Scripts are written and a strict time limit is given to producing it. The expectation is that producing simultaneous interpretation or translation of English scripts into BSL will take approximately the same time and impart the whole message. (Steiner 1998:110)

Close cooperation between program makers and interpreters, therefore, is imperative. The producers of ORF's Wochenschau are aware that the sign language interpreter is an essential part of the team and must be fully integrated in the planning and production of the weekly broadcasts. On Wednesday each week, the editor-in-chief meets with all those involved to discuss the topics and schedule for the upcoming Sunday broadcast.

The Wochenschau is a semi-live broadcast, i.e. it is recorded in toto (as if it were a live program) a day in advance. For the sign language interpreter this means live news interpretation from a set script with time for preparation. The team meets at 12:30 p.m.. At that time the interpreter receives the written script and has about one hour to go through it and clarify points with the editor and news presenter as necessary. After a brief make-up session and a final technical check, the recording starts at 2:15 p.m. in ORF's newsroom, with the new presenter standing next to the news desk (on the right-hand side of the televised image) and the interpreter standing behind the desk (on the left-hand side of the televised image).

In view of the unavoidable, unexpected occasional technical glitches, considerable patience and flexibility are required. In case major events happen between the recording and the airing of the program (i.e. Saturday night or Sunday morning), the program will be updated and the interpreter has to be available for another recording session.

Other important aspects are the appearance and attire of the interpreter. The interpreter should preferably wear plain-colored (gray, brown or black) clothes. 
A survey among deaf and hearing impaired in Great Britain revealed that respondents preferred signers who were pleasant to look at and had 'authority', i.e. were knowledgeable on a given subject:

The aesthetic of the frame was also an important factor. Signers who did not contrast too greatly with picture or colour were preferred. Signers who had 'authority' and were 'pleasing to the eye' were also preferred. (Steiner 1998:137)

\subsection{An additional service}

The Teletext magazine Lesen statt Hoeren (Reading instead of Hearing), a kind of electronic newspaper, complements ORF's services for the deaf and hearing impaired.

\section{ORF as compared with other German-language broadcasters}

Owing to the different socio-political, legal and economic conditions in the European countries, the only comparison that makes sense is between ORF and the other German-language broadcasters.

Figure 2 gives an overview of the services which Austrian, German and Swiss broadcasters provide for their deaf and hearing-impaired audiences.

FIG. 2

German-language broadcasters' services for the deaf and hearing impaired

\begin{tabular}{|l|l|l|}
\hline Broadcaster & Captions & Sign language \\
\hline ORF & 180 hours/month & $\begin{array}{l}\text { 1 weekly magazine } \\
\text { Wochenschau } \\
\text { (sign language \& captions) }\end{array}$ \\
\hline ARD & 100 hours / month & $\begin{array}{l}1 \text { special weekly magazine } \\
\text { Sehen statt hoeren } \\
\text { (sign language \& captions) }\end{array}$ \\
\hline ZDF & 100 hours / month & - \\
\hline PHOENIX & - & $\begin{array}{l}\text { daily news } \\
\text { (Tagesschau/ARD, } \\
\text { heute-journal/ZDF })\end{array}$ \\
\hline SF/DRS & - & - \\
\hline
\end{tabular}

* ARD's and ZDF's satellite channel

** German-language Swiss program

Pro7 is the only private German TV broadcaster so far that airs one captioned feature film per week.

This overview shows that - as regards captioned TV programs for the deaf and hearing impaired - ORF holds a leading position among German-language broadcasting organizations. 


\section{Future perspectives}

Even though the deaf and hearing impaired greatly appreciate the services ORF provides for them, they would favor an expansion of both the use of captions and sign language interpreting on television. Among their priorities is access to television broadcasts produced by the local stations. Another drawback they see is that young deaf children with no or very limited reading skills have no access to ORF's children programs so far.

Ideally, the deaf and hearing impaired would like to have access to all ORF television programs. In discussions with ORF management three major wishes were voiced:

- captions or sign language interpreting for Bundesland heute, a regional program;

- captions or sign language interpreting for special live news broadcasts (e.g. live TV coverage of 9/11),

- more captioned feature films and TV series.

For the Deaf community the request for more sign language interpreting on television is closely linked with their efforts at having sign language recognized as a language in its own right.

Even though, according to the World Federation of the Deaf, sign language interpreters are the principal means by which deaf individuals gain access to the facilities, services and information of the larger communities in which they live. Sign language interpreters are thus a crucial mechanism by which deaf individuals obtain equal access and the same opportunities as the hearing individuals in any society (Mäkipää \& Hämesalo 1993:9). It can be argued that "deaf people have had limited opportunity to watch sign language as a major source of information on television" (Steiner 1998:134).

Providing the deaf and hearing impaired with adequate access to relevant information on television is a significant step towards helping them become responsible, autonomous citizens:

L'interprétation permet aux sourds d'avoir accès in vivo à l'information. Autrefois, il y a une vingtaine d'années, en matière de politique les sourds étaient très influencés par leur entourage immédiat, souvent ils votaient comme leurs parents. Ils n'avaient pas accès aux débats télévisés à l'occasion desquels les candidats présentent leur programme. Désormais, des meetings sont interprétés, le débat opposant les deux candidats à la dernière élection présidentielle a été rediffusée accompagné d'une interprétation en LSF. Cela représente un gros progrès. Si on leur en donne les moyens, les sourds peuvent être des citoyens responsables et autonomes. (Seleskovitch 1997:562)

\section{REFERENCES}

De Linde, Z. (1996): “Le sous-titrage intralinguistique pour les sourds et les mal entendants" in: Y. GAMBier (éd.), pp. 173-183.

Gambier, Y. (éd.) (1996): Les transferts linguistiques dans les médias audiovisuels, Villeneuve d'Ascq (Nord): Presses Universitaires du Septentrion.

Grbić, N. (2002): “Kein Fall für Notfälle. Gebärdensprachdolmetschen," in: I. Kurz and A. Moisl (eds.) Berufsbilder für Übersetzer und Dolmetscher. Perspektiven nach dem Studium, Wien: WUV-Universitätsverlag, pp. 181-189.

Kellett Bidoli, C. J. (2001): “Sign language: A newcomer to the interpreting forum," The Interpreters' Newsletter 11, pp. 131-151. 
KLestiL, T. (1995): "Message to the XIIth World Congress of the World Federation of the Deaf," Vienna: Official Congress Program, p. 1.

Kurz, I. (1990): “Overcoming Language Barriers in European Television," in: D. \& M. Bowen (eds.) Interpreting - Yesterday, Today and Tomorrow, Binghamton NY: SUNY (= ATA Scholarly Monograph Series IV), pp. 168-175.

Kurz, I. (1997): “Getting the Message Across - Simultaneous Interpreting for the Media," in: M. Snell-Hornby, S. Jettmarová and K. Kaindl (eds.) Translation as Intercultural Communication. Selected Papers from the EST Congress, Prague 1995, Amsterdam/Philadelphia: Benjamins, pp. 195-205.

Kurz, I. et E. Bros-Brann (1996): L'interprétation en direct pour la télévision, in Y. Gambier (éd.), pp. 207-216.

Mäкipä̈̈, A. and A. Hämesalo (1993): Towards Full Participation and Equal Rights, Helsinki: World Federation of the Deaf.

Moreau, H. (1998): «L'interprétation sur la chaîne ARTE», in: Y. GAmbier (ed.) Translating for the Media, Turku: Painosalama OY, pp. 225-229.

Seleskovitch, D. (1997): "Interview de Mme Arlette Morel, présidente de la Féderation nationale des sourds de France," META 42/3, pp. 560-63.

Steiner, B. (1998): "Signs from the Void: The Comprehension and Production of Sign Language on Television," Interpreting 3/2, pp. 99-146. 